\title{
Ludowe pojmowanie wiary w kompozycji Missa sine nomine Ignacego Zalewskiego
}

\section{THE FOLK CONCEPTION OF FAITH BASED ON THE COMPOSITION MISSA SINE NOMINE BY IGNACY ZALEWSKI}

The preelection is based on published in 2017 book Sacrum and profanum in coral-percussion music of XXI century by Joanna Maluga and Leszek Lorent. The composition for percussion solo, traditional voice consort (natural voices choir) and four trombones is presented as a centre of the article. Missa sine nomine is an extraordinary composition among others by Zalewski, where he tries to interpret the faith in God interpreted by the institution on Church and by vox populi.

The article shows not only an analysis of the composition, but also a practical way to prererferformance, based mostly on the dialogue between composer and conductor.

Key words: Missa sine nomine, Church, people, faith, God, choir, natural voice.

Missa sine nomine Ignacego Zalewskiego należy do dzieł paraliturgicznych. Przeznaczona jest na perkusję solo, zespół śpiewu tradycyjnego (chór białych głosów) i cztery puzony. Utwór został zamówiony w 2016 roku przez Międzynarodowy Festiwal Tradycji i Awangardy Muzycznej Kody. Jego forma ewoluowała, począwszy od wizji rozbudowanego Stabat Mater ${ }^{1}$ na perkusję solo i chór białych głosów, poprzez

$1 \quad$ Należy w tym miejscu nadmienić, iż Stabat Mater Ignacy Zalewski skomponował w 2018 roku. Dzieło jest przeznaczone na chór, perkusję, baryton, głos żeński 
mszę ze składem instrumentalnym rozszerzonym o cztery puzony przeznaczoną do wykonania koncertowego, aż po mszę zawierającą elementy dramatyczne. W takiej właśnie formie - reżyserowanej mszy religijno-świeckiej, dzieło zostało po raz pierwszy przedstawione publiczności przez Chór VRC, solistów i zespół instrumentalny podczas festiwalu Kody w 2017 roku. Omawiany utwór jest dziełem synkretycznym, w którym oprócz tradycyjnych tekstów mszalnych zostały wykorzystane fragmenty wybranych wierszy i poematów Józefa Czechowicza (O Niebie, Świat, Sam), Jana Kasprowicza (***, Święty Boże), Adama Mickiewicza (Broń mnie przed soba samym). Fascynacja polską poezją nie jest zjawiskiem nowym w twórczości muzycznej Ignacego Zalewskiego. Dzieła inspirowane rodzimą literaturą stanowią

Theology of beauty znaczący element artystycznej spuścizny młodego twórcy, zarówno w aspekcie solowym, kameralnym, jak i symfonicznym. Kompozytor swoją postawą twórczą zrzesza wokól siebie grupę osób o podobnych zainteresowaniach, którzy często współkreują ostateczny kształt danych utworów. Z podobną sytuacją mamy do czynienia w przypadku analizowanej w niniejszej wypowiedzi Missa sine nomine. Pierwsza prezentacja sceniczna dzieła była reżyserowana przez Jerzego Machowskiego - bliskiego współpracownika kompozytora, operującego specyficznym, minimalistycznym podejściem do gry aktorskiej, manifestującym się w powierzeniu chórzystom jedynie wybranych jej elementów, zredukowanych do gestów, przemieszczania się w obrębie przestrzeni akustycznej. Kreowanie napięcia wspierane było przez intymną grę świateł symbolizujących Boską Opatrzność oraz cieni, stanowiących jej antytezę, rodzaj alegorycznego przedstawienia zwątpienia w zasadność niebiańskich wyroków. Tego rodzaju idea doskonale sprawdziła się w warunkach koncertowych Sali Centrum Spotkania Kultur w Lublinie, w której utwór został prawykonany.

Umiejętność doboru odpowiednich tekstów kompatybilnych pod względem treści i emocji do ordinarium i proprium missae w sposób niewątpliwy świadczy o kunszcie kompozytorskim Zalewskiego, wiedzy z zakresu literatury i wyczuciu poetyckiego piękna. Pomimo wprowadzenia do kompozycji świeckich tekstów o ludowym zabarwieniu emocjonalnym, kompozytor nie odcina się od tradycji, czyniąc tym samym ukłon $\mathrm{w}$ stronę słuchaczy zaznajomionych $\mathrm{z}$ wielowiekową schedą języka łacińskiego wykorzystywanego w twórczości religijnej (tu: chrześcijańskiej). W zastosowanych przez Zalewskiego tekstach

i zespół instrumentalny. Prawykonanie dzieła odbędzie się na Festiwalu Gorzkie Żale - Nowe Epifanie, 04.03.2018 roku w Studiu Koncertowym Polskiego Radia im. Witolda Lutosławskiego. 
świeckich występuje motyw zwątpienia w naturę Boga i Jego istotę, akcentujący prostotę pojmowania wyższego bytu przez prostych ludzi. Kompozytor wyraża owo zwątpienie brzmieniem białych głosów chóralnych, nawiązując tym samym do obrzędowości ludowej, często (choć nie w analizowanym przypadku) łączącej elementy ceremoniału chrześcijańskiego z wpływami pogańskimi (np. obrzęd Dziadów).

Teksty ordinarium missae przywoływane przez lud (chór) reprezentują stanowisko instytucji Kościoła, objaśniającej zagadnienia wiary przez pryzmat mędrców i dokonywanej przez nich interpretacji świętych pism. Istota Stwórcy jest jednak nieodgadniona, a Jego wyroki często sprzeczne z ziemskim pojmowaniem sprawiedliwości czy dobra. Boska potęga nie jest rozpoznawalna, lecz jest niezwykle mocno ukonstytuowana kulturowo - ten fakt właśnie nakazuje prostemu ludowi modlitwę nawet w sytuacjach, w których odwoływanie się do Boskiego majestatu wydaje sie być sprzeczne ze zwykłą, ,ziemską logiką”. Człowiek jednak jest $\mathrm{z}$ natury istotą wątpiącą. W analizowanym utworze owa nieufność wyrażona została przez teksty poetyckie. Mamy więc do czynienia z dwiema płaszczyznami narracyjnymi dzieła: płaszczyzną definiowaną przez ordinarium missae oraz świecką, obrazowaną przez teksty spoza łacińskiego obrządku. Zderzenie ze sobą dwóch sposobów narracyjnych generuje napięcia energetyczne. Dualizm Missa sine nomine przejawia się również w użytych przez kompozytora językach polskim i łacińskim. Teksty w języku polskim stanowią komentarz do tekstów łacińskich; są rodzajem ludowej egzegezy świętych pism, przybierając względem nich funkcję afirmatywną lub przeciwstawną. Należy nadmienić, iż Ignacy Zalewski pozostaje sceptyczny w kwestii podejścia do wiary. Jego światopogląd ukonstytuowany został w oparciu o naukowe tezy, o czym wyczytać możemy m.in. wydanej niedawno pozycji autorstwa Leszka Lorenta i Joanny Malugi Sacrum i profanum w chóralno-perkusyjnej muzyce XXI wieku:

Ignacy Zalewski należy do twórców zafascynowanych nauką [...] Fakt ten sprawia, iż kompozytor wizję świata duchowego wywodzi nie z konkretnej doktryny religijnej, narzucającej określone formy rozumowania i postrzegania rzeczywistości lecz z nauki, opierając się na wypowiedziach wielkich jej przedstawicieli, jak choćby Richard Dawkins, Stephen Hawking, Michał Heller².

Można pokusić się o tezę, iż paraliturgiczna twórczość Zalewskiego, w której wykorzystuje teksty spoza kanonu mszalnego, jest formą konsensusu pomiędzy jego własnym sposobem oglądu rzeczywistości

$2 \quad$ J. Maluga, L. Lorent, Sacrum i profanum w chóralno-perkusyjnej muzyce XXI wieku, Bydgoszcz 2017, s. 20. 
Theology of beauty

a postrzeganiem jej przez pryzmat dogmatów chrześcijańskich stojących często w opozycji do „pierwotnego instynktu”, czy też ludowego pojmowania wiary. Poniżej przedstawiony został synkretyczny opis poszczególnych części mszy, koncentrujący się na ich literackiej interpretacji:

- Kyrie - tekst łaciński został skomentowany wierszem Józefa Czechowicza $O$ niebie. Punktem centralnym omawianej części czyni kompozytor słowa „warto śpiewać Jego chwałę”, stanowiące o zasadności wzywania Boskiego miłosierdzia. Kończące fragment słowa „mój synku”, są pierwszym w dziele wyrazem zwątpienia i rzeczywistego, ludzkiego cierpienia po stracie ukochanej, bliskiej osoby. Ignacy Zalewski określił owo zwątpienie jako „niezwykle osobiste, wynikające z prostoty ducha gminu"3.

- Gloria - poetycki komentarz do Glorii pozostaje względem niej w opozycji. Obrzęd mszalny, generujący uwielbienie nieznanego prostemu ludowi Boga zderza się z rozpaczą, i łzami których rezonans odnajdujemy w kolejnych częściach kompozycji („wierzyłem zawsze w światła moc, władnącą nad mrokami, a przecież nieraz wiarę tę gorzkimi zlewam łzami”).

- Credo - część ta ma charakter hiobowy. Takie widzenie Symbolu Nicejskiego stanowi zamierzony przez twórcę paradoks. Oto bowiem wyznanie wiary zderza się z rozpaczą rodzącą gniew i sprzeciw. Zwrot „Broń mnie przed sobą samym” oznacza w tym wypadku dyskurs między duchem (ludzką duszą) a materią (ludzką cielesnością) . Samo słowo credo (wierzę) reprezentuje irracjonalną cząstkę natury ludzkiej, która $\mathrm{z}$ jednej strony jednoczy lud, narzucając mu normy postępowania i zachowania, z drugiej zaś rodzi pytania, wątpliwości i pragnienie wiedzy. Należy jednak zwrócić uwagę na fakt, iż zdobycie całkowitej wiedzy przekreśla Tajemnicę Wiary będącą jej esencją. Część Credo zakończona została ontologicznym pytaniem o istotę Boga - człowieka.

- Sanctus - tekst mszalny pozostaje w opozycji do poetyckiego komentarza. Uporczywie powtarzane Sanctus Dominus Deus Sabaoth współistnieje z obrazem konającego człowieka będącego podmiotem lirycznym w wierszu Jana Kasprowicza. Odbiorcy poezji mogą odnieść wrażenie, że Bóg pozostaje w pewien sposób na uboczu rozgrywających się w materialnym świecie ludzkich dramatów. Jego siła i potęga współistnieją z obojętnością i stałością (niezmiennością) Jego istoty. Zarysowana w Glorii niemoc istoty ludzkiej przybiera w tej części silniejszy, choć ukryty charakter. Kompozytor, poprzez określone

$3 \quad$ Autoryzowana wypowiedź kompozytora z dnia 05.07.2016 - rozmowa z Joanną Malugą i Leszkiem Lorentem. 
zabiegi artykulacyjne uwydatnia melodykę tekstu młodopolskiego poety (zaakcentowanie przedniojęzykowej głoski „r" w siedmiokrotnej repetycji słów „kracze i kracze”).

- Agnus Dei - część ta symbolizuje pogodzenie sie z faktem przemijania. Kompozytor osiąga ów efekt poprzez połączenie poezji Józefa Czechowicza z tekstem łacińskim. Szczególną uwagę zwraca Zalewski na zagadnienie upływającego czasu ${ }^{4}$, który w ludzkim (ziemskim) pojmowaniu zbliża człowieka w stronę śmierci, unicestwienia, w Boskim zaś - ku wieczności. Ontologiczny problem odnoszący się do istnienia Boga odnajdujemy w słowach ,jest”, „nie ma”, „będzie”, „był”. Jest to centralny punkt energetyczny omawianej części.

W analizowanej kompozycji pojawiają się liczne opozycje wynikające z przekazu użytych tekstów polskich i łacińskich. Głos ludu (vox populi) stara się pojąć transcendentne treści stanowiące esencję wiary i przełożyć je na realia codziennego, ziemskiego życia. Jest to jednak zadanie zdecydowanie wykraczające poza możliwości percepcyjne człowieka $\mathrm{z}$ gminu martwiącego się $\mathrm{w}$ większej mierze o zaspokojenie podstawowych potrzeb życiowych niż o sprawy ducha. Ukryty za skomplikowanymi rytuałami Bóg, który dwa tysiące lat temu wcielił się w postać człowieka, nie przemawia do prostych ludzi, pozostając tym samym obcym bytem. Boskie człowieczeństwo Jezusa Chrystusa percypowane jest przez lud jedynie w formie wyuczonych przez wieki historii form niedzielnych i świątecznych zachowań, przybierających często formę jedynie gestów wykonywanych poniekąd w sposób automatyczny. W cytowanej już książce Sacrum i profanum w chóralno-perkusyjnej muzyce XXI wieku wyczytać możemy, iż w analizowanym dziele

kompozytor, poprzez swe muzyczno-poetyckie przemyślenia kieruje uwagę odbiorcy dzieła ku teologii negatywnej - tzw. teologii apofatycznej, według której częściowy wgląd w istotę Boga uzyskujemy poprzez zaprzeczenia, czym lub kim Bóg nie jest ${ }^{5}$.

$4 \quad$ Zagadnienie upływającego czasu poruszane jest przez Ignacego Zalewskiego w wielu kompozycjach. Ma to niewątpliwy związek z zainteresowaniem kompozytora mechaniką kwantową i publikacjami prof. Michała Hellera. Ignacy Zalewski w jednym z wywiadów udzielonych nam podczas pracy nad książką wyznał, iż mimo fascynacji nauką nigdy nie stara się przekładać jej języka na sposób muzycznej wypowiedzi w sposób ścisły. Scjentyczne inspiracje powinny bowiem stanowić jedynie pretekst do głębszych rozważań na polu sztuki. Według Zalewskiego nauka i sztuka odpowiadają innym potrzebom człowieka i nie powinno się ich łączyć.

$5 \quad$ J. Maluga, L. Lorent, Sacrum i profanum..., s. 39. 
Theology of beauty

Omawiane dzieło Ignacego Zalewskiego z całą pewnością nie należy do klasyki gatunku. Mimo iż w tytule kompozycji widnieje słowo msza, w sposób znaczący odbiega ona treścią i przekazem od jej tradycyjnej formy. Dzieje się tak zapewne nie tylko ze względu na wprowadzenie do „muzycznego obrządku” tekstów poetyckich, lecz przede wszytkim ze względu na jej przekaz filozoficzny akcentujący zwątpienie w Boga. Mamy zatem do czynienia z kolejnym paradoksem, w którym doświadczenie sacrum współistnieje czy wręcz współzawodniczy z codziennym postrzeganiem profanum: duch zderza się z materią, życie ze śmiercią, wieczność z przemijaniem...

Missa sine nomine zrodziła się z potrzeby refleksji nad rytuałem oraz chęcią wniknięcia głębiej w psychologię ludzkiego przeżywania tegoż rytuału, w trakcie którego oprócz tradycyjnych formuł obecna jest własna, wewnętrzna refleksja każdego człowieka ${ }^{6}$.

\section{Chór w kompozycji Missa sine nomine Ignacego Zalewskiego}

Utwór Missa sine nomine w pierwotnym zamyśle kompozytorskim miał być wykony przez zespół śpiewu tradycyjnego. W niedługim czasie Zalewski zmienił jednak koncepcję ze względu na potencjalne ograniczenia wyrazowe, jakie niesie za sobą zastosowanie jedynie białych głosów, w sposób naturalny predestynowanych do wykonawstwa muzyki ludowej.

W przypadku realizacji dzieła przez Chór VRC kompozytor zmienił początkowe założenia estetyczne przez wprowadzenie większej liczby barwowych niuansów, elementów współczesnych technik kompozytorskich. Jednym z powodów owych zmian były nowe możliwości wykonawcze, jakie otworzyły się przed Zalewskim podczas współpracy z Chórem VRC, specjalizującym się w realizacji partytur muzyki współczesnej, choć nie tylko. Należy bowiem nadmienić, iż wspomniany zespół z równą gracją porusza się we współczesnych estetykach muzycznych jak i doskonale odnajduje się w realizacji muzyki minionych epok. Dzięki ciągłemu poszerzaniu wiedzy z zakresu technik wykonawczych Chór VRC operuje szerokim diapazonem możliwości artykulacyjnych i wyrazowych. Muzycy tworzący trzon zespołu posiadają szerokie horyzonty artystyczne i często nie ograniczają swych projekcji jedynie do śpiewu. Należy w tym miejscu przywołać wykonania licznych utworów, w których chórzyści śpiewając grali również na drobnych

$6 \quad$ Autoryzowana wypowiedź kompozytora z dnia 05.07.2016 - rozmowa z Joanną Malugą i Leszkiem Lorentem. 
instrumentach perkusyjnych takich jak rain makery, czy simantry. Do dzieł tego rodzaju należą m.in.: Xopancuicatl Piotra Tabakiernika, Messa dell Uomo Moderno Kamila Staszowskiego.

Kompozytor miał zatem do dyspozycji niezwykły aparat wykonawczy, z jednej strony operujący klasyczną, wyrównaną barwą, z drugiej, potrafiący przekroczyć kanony klasycznego śpiewu wchodząc tym samym w arkana muzyki tradycyjnej, zarezerwowanej niejako dla ludowych (lub stylizowanych na nie) formacji artystycznych.

Nowe założenia kompozytorskie, będące wynikiem wnikliwej współpracy między kompozytorem, dyrygentem a w konsekwencji z całym zespołem zostały ujęte w następujący sposób:

- elementy dzieła utrzymane w niskich wartościach dynamicznych, posiadające charakter kontemplacyjny winny być stylizowane na naturalny śpiew odznaczający się „nieokrzesaną” barwą głosu znaną z wiejskich kościołów;

- fragmenty kompozycji utrzymane w wysokich wartościach dynamicznych, odznaczające się dużą energetyką, powinny przypominać krzyk realizowany na konkretnych, zdeterminowanych zapisem wysokościowym dźwiękach.

Obydwa powyższe założenia generowały ogromny wysiłek wokalny, dlatego w fazie odczytywania utworu zespół pracował według zasad klasycznej emisji głosu. Podczas ostatnich prób, posiadając już doświadczenie operowania głosem białym (zdobyte podczas warsztatów) chór realizował wiernie wskazówki kompozytorskie.

Jak już zostało wcześniej wspomniane, Ignacemu Zalewskiemu chodziło o przedstawienie nabożeństwa, w którym wierni w sposób rzeczywisty rozważają zagadnienie Bożej obecności. Rzeczywisty oznacza w tym miejscu ludzki, prosty sposób pojmowania Boga, stojący często w sprzeczności z oficjalną nauką Kościoła. Literackim obrazem tego typu rozterek, będący rodzajem swoistej dychotomii dzielącej „pokornego ducha” i „niepokorne ciało” mogą być wybrane fragmenty dzieła Stanisława Reymonta Chłopi, w których autor zawarł opis zaduszkowych nabożeństw, łączonych po kryjomu z dawnym obrządkiem Dziadów. W utworze Zalewskiego spod płaszczyzny żarliwej modlitwy prostego ludu wyłaniają się pytania o naturę Boga. Zderzenie dwóch postaw mentalnych uczestników nabożeństwa, ufnej i skontrastowanej z nią wątpiącej, rodzi emocje. Generuje także konieczność zróżnicowania sposobów chóralnej artykulacji dźwięku. Twórca stawia w centrum dzieła człowieka rozdartego wewnętrznie między wynikającą z tradycji koniecznością słuchania Bożego Słowa a jego rozumieniem. Kompozytor podkreśla, iż w jego mszy: „,chodzi o przedstawienie nabożeństwa, 
podczas którego ludziom puszczają hamulce, jeśli mają wątpliwości co do tak sformułowanej wiary, bożej obecności, czy po prostu do kondycji w świecie i jakości życia"7. Nie znaczy to jednak, iż analizowany utwór ma charakter obrazoburczy. Lepszym określeniem tego typu zabiegów jest przebijająca przez sferę sacrum świeckość, której literackim wcieleniem są teksty poetyckie. Chodzi tutaj o ludzkie pojmowanie wiary, pociągające za sobą cały bagaż ułomności wynikających z naturalnych ograniczeń człowieka. Ignacy Zalewski kieruje swe dzieło do inteligentnych, wolnych od uprzedzeń słuchaczy, prowokując do rozważań nad chrześcijańskim rytuałem. Jako podsumowanie warto jeszcze raz zacytować Zalewskiego:

Theology of beauty

Ostatnim o co mi chodzi byłoby stworzenie obrazoburczego widowiska. Chciałbym spojrzeć na odczuwanie transcendencji na bardzo intymnym poziomie, do którego dostęp daje w pewnym sensie nieokrzesany technicznie śpiew. Ale przede wszystkim z poczuciem, że potrzeba uczestnictwa w rytualne znaczącym, symbolicznym, jest ważna, jeżeli nie niezbędna dla człowieka ${ }^{8}$.

Kompozytor nie bez przyczyny zatytułował swoje dzieło Missa sine nomine. Nawiązał w ten sposób do renesansowej tradycji mszalnej sine nomine. W książeczce programowej Festiwalu Tradycji i Awangardy Muzycznej KODY 2017 czytamy:
Missa sine nomine - dosłownie „Msza bez nazwy”, to tradycyjna nazwa powstałego $\mathrm{w}$ renesansie takiego umuzycznienia ordinarium missae, w którym kompozytor operuje wyłącznie skomponowanym prze siebie materiałem dźwiękowym. W Missa sine nomine Ignacego Zalewskiego swobodzie kompozytorskiej podlega nie tylko materiał muzyczny, ale do pewnego stopnia również materiał słowny: obok tekstu mszy śpie- wanego po łacinie, w utworze występują fragmenty wierszy i poematów Adama Mickiewicza, Józefa Czechowicza i Jana Kasprowicza. W kom- pozycji znajdują się również cytaty melodyczne z dwóch znanych pieśni ludowych: kurpiowskiej - Zaświeć niesiondzu i lubelskiej - Kare konie.

W głębszym, metafizycznym znaczeniu, przez określenie sine nomine kompozytor dokonuje pewnego uogólnienia na płaszczyźnie duchowej. Mimo iż termin msza odwołuje się zazwyczaj do chrześcijańskiej duchowości, Zalewski niejako jej nie nazywając odwołuje się w swym muzyczno-metafizycznych rozważaniach do ogólnego widzenia ducha. Nie upatruje bowiem esencji wiary w usankcjonowanej

\footnotetext{
$7 \quad$ Autoryzowana wypowiedź kompozytora z dnia 05.07.2016 - rozmowa z Joanną Malugą i Leszkiem Lorentem. 
instytucjonalnie formie obrządku lecz w jej recepcji dokonywanej przez prosty lud, a więc w szerszym znaczeniu również przez każdego człowieka.

Podsumowując wszystkie rozważania na temat Missa sine nomine Ignacego Zalewskiego pragnę przywołać słowa kompozytora, w których streszcza idee dzieła:

W Missa sine nomine własna, wewnętrzna refleksja każdego człowieka nad sacrum jest niejako wyciągnięta na wierzch za pomocą poezji wybranych autorów. Refleksja ta czasem może być bardzo powszednia, przyziemna, czasem wątpiąca, czasem afirmatywna, czasem wręcz epifaniczna. Takie właśnie spojrzenie na ludzkie przeżywanie chciałem zawrzeć w mszy, aby odświeżyć swoje i słuchacza podejście do rytuału naszej kulturze najbliższemu i najbardziej powszedniemu oraz zobaczyć, co z tego wyniknie. Podobnie jak w Stojąc $z$ daleka, tak i tu nie stawiam tez, nie prawię morałów i nie wchodzę w żadną teologiczną czy mistyczną dyskusję. Wyjąwszy wstawki z tekstami poetyckimi Missa sine nomine jest kolejnym umuzycznieniem ordinarium missae, a każdy słuchacz może wynieść z utworu to, co chce i odnieść (lub nie odnosić) do własnego przeżywania i własnej, prywatnej metafizyki. Koniec końców jednak muzyką staram się przede wszystkim oddziaływać na emocje, bo ostatecznie o to po prostu chodzi w komponowaniu?.

\section{LUDOWE POJMOWANIE WIARY W KOMPOZYCJI MISSA SINE NOMINE IGNACEGO ZALEWSKIEGO}

Niniejszy artykuł powstał w oparciu o wydaną w 2017 roku książkę Sacrum i profanum w chóralno-perkusyjnej muzyce XXI wieku ${ }^{10}$ autorstwa Joanny Malugi i Leszka Lorenta. Przedstawione w nim rozważania dotyczą synkretycznej kompozycji Ignacego Zalewskiego przeznaczonej na perkusję solo, zespół śpiewu tradycyjnego (chór białych głosów) i cztery puzony. Missa sine nomine należy do szczególnych dzieł w dorobku młodego twórcy, w którym podejmuje on zagadnienia wiary w Boga interpretowanej przez instytucję Kościoła oraz przez prosty lud. Dyskurs, który pojawia się przy tak zarysowanym zagadnieniu stanowi główną treść dzieła. Prezentowany tekst w dużej mierze stanowi o rozumieniu analizowanego utworu, w oparciu o praktykę wykonawczą autorki oraz o rozmowy z twórcą

Słowa kluczowe: Missa sine nomine, Kościół, lud, wiara, Bóg, chór, białe głosy.

\footnotetext{
$9 \quad$ Ibidem.

10 J. Maluga, L. Lorent, Sacrum i profanum...
}

Theology of beauty 


\section{Bibliografia:}

1. Borowska B., Inspirujaca rola tekstów maryjnych $w$ ksztattowaniu frazy i interpretacji utworów chóralnych kompozytorów polskich, Katowice 2011.

2. Czechowicz, J., Kamien, Lublin 2007.

3. Czechowicz, J., Wiersze wybrane, Warszawa, 1955.

4. Dąbek S., Twórczość mszalna kompozytorów polskich XX wieku, Warszawa 1996.

5. Farcinkiewicz Ł., Tworzenie muzyki sakralnej, rozmowa z Pawłem Łukaszewskim, [w:] Musica Sacra Nova 1/2007, red. M. Eukaszewski, Warszawa 2007.

6. Kasprowicz, J., Hymny, Księga Ubogich, Mój Świat, Warszawa, 1956.

7. Łukaszewska J., Świadomość podstawa prawidłowej mowy i śpiewu, [w:] Musica Sacra Nova 3-4, Warszawa 2009.

Theology

of beauty

8. Maluga J., Lorent L., Sacrum i profanum w chóralno-perkusyjnej muzyce XXI wieku, Bydgoszcz 2017.

9. Mickiewicz, A., Wiersze i powieści poetyckie, Warszawa, 1998.

10. Mielko-Remiszewska M., Musica Ecclesiae Nova, Lublin 2010.

11. Stochniol M., Pasja w XX wieku, „Ruch Muzyczny” 2012, nr 6.

12. Szulik M.R., Chór w kościele, Lublin 2012.

13. Autoryzowane wywiady z kompozytorem. 